JKT, 2017;8(2):84-93. Hubungan antara Asupan Protein, Zat Besi, Vitamin C, Allia Khairunnisa, I Dewa Putu Pramantara, Weni Kurdanti

\title{
HUBUNGAN ANTARA ASUPAN PROTEIN, ZAT BESI, VITAMIN C, DAN INHIBITOR ABSORPSI ZAT BESI DENGAN STATUS ANEMIA PADA LANJUT USIA DI PAGUYUBAN “WIRA WREDHA" WIROGUNAN, YOGYAKARTA
}

The Relationship between Intake of Protein, Iron, Vitamin C, and Iron Absorption Inhibitors with Anemia Status in Older People at Paguyuban "Wira Wredha” Wirogunan, Yogyakarta

\author{
Allia Khairunnisa ${ }^{1}$, I Dewa Putu Pramantara ${ }^{2}$, Weni Kurdanti ${ }^{3}$ \\ ${ }^{1}$ Program Studi Gizi Kesehatan Fakultas Kedokteran Universitas Gadjah Mada, Jalan Farmako, Sekip \\ Utara, Yogyakarta \\ ${ }^{2}$ Departemen Geriatri RSUP Dr. Sardjito, Jalan Kesehatan 1, Kec. Mlati, Kabupaten Sleman, \\ Yogyakarta \\ ${ }^{3}$ Jurusan Gizi Poltekkes Kemenkes Yogyakarta, Jalan Tatabumi 3, Banyuraden, Gamping, Sleman, \\ Yogyakarta \\ E-mail: allia.khair08@gmail.com
}

\begin{abstract}
The prevalence of anemia in older people based on data from NHANES III by 11,0\% of men and 10,2\% of women suffered from anemia. The study used observational study with cross sectional design. Subjects for the study were 99 older people at Paguyuban "Wira Wredha" Wirogunan, Yogyakarta who complied for inclusion and exclusion criteria. Data collected include protein intake, iron intake, vitamin C intake, iron absorption inhibitors intake, body weight, and hemoglobin concentration. Data related to intake of protein, iron, vitamin $\mathrm{C}$, and iron absorption inhibitors obtained by interview using SQFFQ. Body weight measured using weight scales. Hemoglobin concentration measured using hemocue method. The statistical test used to analyze the relationship is a Chi Square test or Fisher's exact test. The prevalence of anemia in older people was $18,2 \%$. There was significant relationship between intake of protein $(p=0,005)$ and iron $(p=0,007)$ with anemia status in older people. There was no significant relationship between intake of vitamin $\mathrm{C}(\mathrm{p}=0,636)$, iron absorption inhibitors (tannin, phytate, oxalate acid) with anemia status in older people $(\mathrm{p}=0,184 ; \mathrm{p}=0,129 ; \mathrm{p}=0,393)$ with anemia status in older people. There were significant relationship between intake of protein and iron with anemia status in older people at Paguyuban "Wira Wredha" Wirogunan, Yogyakarta. There were no significant relationship between intake of vitamin $\mathrm{C}$ and iron absorption inhibitors with anemia status in older people at Paguyuban "Wira Wredha" Wirogunan, Yogyakarta.
\end{abstract}

Keywords: Anemia status, iron, iron absorption inhibitors, protein, vitamin C

\begin{abstract}
ABSTRAK
Prevalensi anemia pada lanjut usia berdasarkan data NHANES III sebesar 11,0\% laki-laki dan 10,2\% perempuan menderita anemia. Jenis penelitian yang dilakukan adalah penelitian observasional dengan rancangan cross-sectional. Subjek penelitian adalah 99 orang lanjut usia di Paguyuban "Wira Wredha" Wirogunan, Yogyakarta. Data yang dikumpulkan yaitu asupan protein, asupan zat besi, asupan vitamin $\mathrm{C}$, asupan inhibitor absorpsi zat besi, berat badan, dan kadar hemoglobin. Data asupan protein, zat besi, vitamin $\mathrm{C}$, dan inhibitor absorpsi zat besi diperoleh dengan wawancara menggunakan SQFFQ. Berat badan diukur dengan menggunakan timbangan berat badan. Kadar hemoglobin diukur dengan menggunakan metode hemocue. Uji statistik yang digunakan untuk menganalisis hubungan adalah uji Chi Square atau uji Fisher's exact. Prevalensi anemia pada lanjut usia adalah 18,2\%. Ada hubungan yang bermakna antara asupan protein $(\mathrm{p}=0,005)$ dan zat besi $(\mathrm{p}=0,007)$ dengan status anemia pada lanjut usia. Tidak ada hubungan yang bermakna antara asupan vitamin $\mathrm{C}(\mathrm{p}=0,636)$ dan asupan inhibitor absorpsi zat besi (tanin, fitat, asam oksalat) dengan status anemia pada lanjut usia ( $p=0,184 ; p=0,129 ; p=0,393)$. Ada hubungan yang bermakna antara asupan protein dan zat besi dengan status anemia serta tidak ada hubungan yang bermakna antara asupan vitamin $\mathrm{C}$ dan inhibitor absorpsi zat besi dengan status anemia pada lanjut usia di Paguyuban "Wira Wredha" Wirogunan, Yogyakarta.
\end{abstract}

Kata kunci: Inhibitor absorpsi zat besi, protein, status anemia, vitamin C, zat besi 
JKT, 2017;8(2):84-93. Hubungan antara Asupan Protein, Zat Besi, Vitamin C, Allia Khairunnisa, I Dewa Putu Pramantara, Weni Kurdanti

\section{PENDAHULUAN}

Prevalensi anemia pada lansia berdasarkan data NHANES III menunjukkan bahwa 11,0\% laki-laki dan $10,2 \%$ perempuan menderita anemia ${ }^{(1)}$. Anemia terus meningkat seiring pertambahan usia. Pada usia 65-69 tahun, onset kejadian anemia adalah 6\% pada laki-laki dan $4 \%$ pada perempuan. Pada usia 85 tahun atau lebih, kejadian anemia akan naik menjadi 14\% pada laki-laki dan $13 \%$ pada perempuan. Anemia merupakan faktor risiko yang dapat meningkatkan morbiditas dan mortalitas serta menurunkan kualitas hidup pada lanjut usia. Penurunan sistem fungsional berkaitan dengan penurunan konsentrasi hemoglobin ${ }^{(2)}$.

Kelompok lansia pada umumnya memiliki gigi yang tidak sempurna lagi, sehingga mempunyai keterbatasan dalam mengonsumsi zat besi yang bersumber dari hewani (heme iron), akibatnya lansia sangat rentan terhadap kejadian anemia. Walaupun lansia dapat mengonsumsi zat besi sumber nabati, namun apabila dikonsumsi bersama-sama dengan inhibitor absorpsi zat besi maka penyerapan zat besinya akan terhambat, sehingga lansia tersebut tetap rentan terhadap kejadian anemia ${ }^{(3)}$.

Anemia pada lanjut usia disebabkan oleh anemia karena kehilangan darah/kurang gizi (nutritional anemia) sebesar 34\%, anemia pada penyakit kronik/peradangan sebesar 32\%, dan anemia yang tidak diketahui penyebabnya (unexplained anemia) sebesar $34 \%^{(1)}$. Anemia defisiensi besi merupakan penyakit nomor satu terbanyak yang diderita oleh lansia di Indonesia dengan angka kejadian sebesar $50 \%^{(3)}$.

Lanjut usia sering mengalami masalah gizi yang dapat menyebabkan gangguan pada kadar hemoglobin karena kurangnya asupan zat gizi seperti zat besi, asam folat, vitamin B12 yang sangat dibutuhkan untuk pembentukan sel-sel darah, dan zat gizi lainnya yang juga sangat dibutuhkan seperti protein, vitamin C, piridoksin, copper ${ }^{(4)}$.

Sumber protein hewani dapat meningkatkan absorpsi zat besi nonheme karena sumber protein hewani mengandung zat besi heme $e^{(5)}$. Asam askorbat pada vitamin $\mathrm{C}$ dapat meningkatkan absorpsi zat besi nonheme di gastrointestinal, terutama jika mengonsumsi beberapa sumber zat besi secara bersamaan ${ }^{(6)}$. Inhibitor absorpsi zat besi merupakan senyawa yang dapat mengganggu atau menghambat absorpsi zat besi meliputi polifenol (tanin), fitat, dan asam oksalat. Polifenol terdapat dalam teh, kopi, kakao, dan anggur merah. Fitat banyak terdapat dalam sereal dan kacang-kacangan. Asam oksalat terdapat dalam sayuran, kacangan-kacangan, serta pada berbagai jenis tepung dari gandum ${ }^{(7,8,9,10)}$.

\section{METODE PENELITIAN}

Jenis penelitian ini merupakan studi observasional dengan rancangan cross-sectional. Penelitian dilaksanakan di Paguyuban "Wira Wredha" Wirogunan, Yogyakarta. Pelaksanaan penelitian dimulai dari bulan Februari 2014 sampai Maret 2014.

Sampel penelitian adalah lanjut usia di Paguyuban "Wira Wredha" Wirogunan, Yogyakarta, dengan kriteria inklusi yaitu berusia $\geq 60$ tahun, tinggal menetap, berkomunikasi aktif dan baik, tercatat di Paguyuban "Wira Wredha", dan setuju ikut penelitian dengan informed consent. Sedangkan kriteria eksklusinya yaitu menderita gagal ginjal, menderita keganasan/kanker, memiliki riwayat perdarahan, dan rutin mengonsumsi tablet tambah darah. Besar sampel dalam penelitian ini adalah 94 orang. Sampel penelitian ditentukan dengan menggunakan purposive sampling.

Setelah menentukan subjek penelitian sesuai kriteria, kemudian subjek diberikan penjelasan calon responden tentang alur penelitian, diminta persetujuan untuk menandatangani informed consent, melakukan wawancara identitas subjek, melakukan wawancara asupan dengan SQFFQ, pengukuran antropometri yaitu menimbang berat badan dengan ketelitian 0,1 $\mathrm{kg}$, dan pengukuran kadar hemoglobin dengan menggunakan metode hemocue.

Variabel bebas adalah asupan protein, asupan zat besi, asupan vitamin C, dan asupan inhibitor absorpsi zat besi. Sedangkan variabel terikatnya adalah status anemia. Data asupan diperoleh melalui wawancara dengan menggunakan Semi Quantitative Food Frequency 
JKT, 2017;8(2):84-93. Hubungan antara Asupan Protein, Zat Besi, Vitamin C,

Allia Khairunnisa, I Dewa Putu Pramantara, Weni Kurdanti

Questionnaire (SQFFQ) yang telah divalidasi sebelumnya. Data status anemia diperoleh melalui pengukuran kadar hemoglobin dengan metode hemocue yang dilakukan oleh lulusan Diploma III Analis Kesehatan.

Asupan protein, asupan zat besi, dan asupan vitamin $\mathrm{C}$ adalah jumlah asupan (protein, zat besi, vitamin C) kemudian dibandingkan dengan AKG 2013 yang dikategorikan kurang bila $<80 \%$ AKG dan cukup bila $\geq 80 \%$ AKG (11). Asupan inhibitor absorpsi zat besi adalah jumlah asupan (tanin, fitat, asam oksalat) kemudian dibandingkan dengan rata-rata seluruh sampel yang dikategorikan tinggi bila di atas rata-rata asupan perhari dan rendah bila di bawah rata-rata asupan perhari (12). Status anemia adalah kadar hemoglobin yang diukur dengan metode hemocue yang dikategorikan anemia bila kadar $\mathrm{Hb}$ darah laki-laki $<13 \mathrm{~g} / \mathrm{dl}$ dan perempuan $<12$ $\mathrm{g} / \mathrm{dl}$ serta tidak anemia bila kadar Hb darah laki-laki $\geq 13 \mathrm{~g} / \mathrm{dl}$ dan perempuan $\geq 12 \mathrm{~g} / \mathrm{dl}^{(1)}$.

Data yang diperoleh diolah dan dianalisis dengan analisis univariat, analisis bivariat, dan analisis multivariat. Analisis univariat digunakan untuk mengetahui distribusi frekuensi asupan protein, zat besi, vitamin $\mathrm{C}$, inhibitor absorpsi zat besi, dan status anemia pada lanjut usia. Analisis bivariat dengan menggunakan uji Chi Square atau alternatif uji Fisher's exact untuk mengetahui hubungan antara asupan protein, zat besi, vitamin $\mathrm{C}$, dan inhibitor absorpsi zat besi dengan status anemia pada lanjut usia serta mengetahui besarnya risiko mengalami anemia pada lanjut usia dari asupan protein, zat besi, vitamin C, dan inhibitor absorpsi zat besi dengan Prevalence Ratio (PR). Analisis multivariat dengan menggunakan regresi logistik untuk mengetahui besarnya kontribusi antara asupan protein, zat besi, vitamin $\mathrm{C}$, dan inhibitor absorpsi zat besi dengan status anemia pada lanjut usia. Penelitian ini telah mendapatkan ethical clearance dari Komisi Etik Fakultas Kedokteran Universitas Gadjah Mada.

\section{HASIL}

Tabel 1. Karakteristik subjek

\begin{tabular}{|c|c|c|}
\hline Karakteristik & $\mathrm{n}$ & $\%$ \\
\hline \multicolumn{3}{|l|}{ Jenis Kelamin } \\
\hline Laki-laki & 31 & 31,3 \\
\hline Perempuan & 68 & 68,7 \\
\hline \multicolumn{3}{|l|}{ Usia (tahun) } \\
\hline $60-74$ & 58 & 58,6 \\
\hline $75-90$ & 40 & 40,4 \\
\hline$>90$ & 1 & 1,0 \\
\hline \multicolumn{3}{|l|}{ Agama } \\
\hline Islam & 71 & 71,7 \\
\hline Kristen & 11 & 11,1 \\
\hline Katholik & 17 & 17,2 \\
\hline \multicolumn{3}{|l|}{ Pendidikan } \\
\hline SD ke bawah & 40 & 40,4 \\
\hline SMP & 20 & 20,2 \\
\hline SMA & 26 & 26,3 \\
\hline Perguruan Tinggi & 13 & 13,1 \\
\hline \multicolumn{3}{|l|}{ Pekerjaan } \\
\hline Tidak bekerja & 75 & 75,8 \\
\hline Wiraswasta/Karyawan Swasta & 24 & 20,2 \\
\hline Buruh & 4 & 4,0 \\
\hline \multicolumn{3}{|l|}{ Kelengkapan Gigi } \\
\hline Lengkap & 4 & 4,0 \\
\hline Tidak lengkap & 95 & 96,0 \\
\hline \multicolumn{3}{|l|}{ Kesulitan Mengunyah } \\
\hline $\mathrm{Ya}$ & 54 & 54,5 \\
\hline Tidak & 45 & 45,5 \\
\hline
\end{tabular}


JKT, 2017;8(2):84-93. Hubungan antara Asupan Protein, Zat Besi, Vitamin C,

Allia Khairunnisa, I Dewa Putu Pramantara, Weni Kurdanti

\section{Karakteristik subjek penelitian}

Sebagian besar subjek adalah perempuan $(68,7 \%)$, berusia $60-74$ tahun $(58,6 \%)$, beragama Islam $(71,7 \%)$, berstatus janda (49,5\%), berpendidikan SMA $(26,3 \%)$, dan sudah tidak bekerja $(45,5 \%)$. Sebagian besar gigi subjek tidak lengkap (96\%) dan mengalami kesulitan mengunyah $(54,5 \%)$ (Tabel 1). Lansia yang memiliki jumlah gigi asli lebih banyak akan berupaya meningkatkan pola makan dan tidak terlalu membatasi asupan. Sedangkan pada lansia yang memiliki jumlah gigi asli lebih sedikit akan mengonsumsi makanan yang lebih lunak. Subjek yang tidak memiliki kelengkapan gigi, beberapa diantaranya menggunakan gigi palsu sehingga tidak mengalami kesulitan mengunyah. Gigi palsu dapat membantu kinerja gigi asli sehingga memberikan kemudahan untuk mengunyah makanan (13).

Tabel 2. Asupan protein, zat besi, vitamin $\mathrm{C}$, dan inhibitor absorpsi zat besi

\begin{tabular}{ccc}
\hline Asupan & $\mathrm{n}$ & $\%$ \\
\hline Protein & 66 & 66,7 \\
Kurang & 33 & 33,3 \\
Cukup & 29 & \\
Zat Besi & 70 & 29,3 \\
Kurang & & \\
Cukup & 50 & 50,7 \\
\hline Vitamin C & 49 & 49,5 \\
Kurang & & \\
Cukup & 47 & 47,5 \\
Tanin & 52 & 52,5 \\
Tinggi & & \\
Rendah & 49 & 49,5 \\
Fitat & 50 & 50,5 \\
Tinggi & & \\
Rendah & 46 & 46,5 \\
Asam Oksalat & 53 & 53,5 \\
Tinggi & &
\end{tabular}

\section{Asupan protein, zat besi, vitamin $\mathrm{C}$, dan inhibitor absorpsi zat besi}

Asupan protein dengan kategori kurang sebesar 66,7\% dan kategori cukup sebesar 33,3\%. Asupan zat besi dengan kategori kurang sebesar 29,3\% dan kategori cukup sebesar 70,7\%. Asupan vitamin C dengan kategori kurang sebesar 50,5\% dan kategori cukup sebesar 49,5\%. Sehingga dapat disimpulkan bahwa sebagian besar subjek memiliki asupan protein kurang, asupan zat besi cukup, dan asupan vitamin C kurang (Tabel 2).

Rata-rata asupan inhibitor absorpsi zat besi tanin adalah $6320,93 \pm 1895,961 \mathrm{mg} / \mathrm{hari}$, fitat adalah $205,29 \pm 70,038 \mathrm{mg} / \mathrm{hari}$, dan asam oksalat adalah 2,8048 $\pm 1,25015 \mathrm{mg} / \mathrm{hari}$. Asupan tanin dengan kategori tinggi sebesar 47,5\% dan kategori rendah sebesar 52,5\%. Asupan fitat dengan kategori tinggi sebesar 49,5\% dan kategori rendah sebesar 50,5\%. Asupan asam oksalat dengan kategori tinggi sebesar 46,5\% dan kategori rendah sebesar 53,5\%. Sehingga dapat disimpulkan bahwa sebagian besar subjek memiliki asupan tanin rendah, asupan fitat rendah, dan asupan asam oksalat rendah (Tabel 2). 
JKT, 2017;8(2):84-93. Hubungan antara Asupan Protein, Zat Besi, Vitamin C,

Allia Khairunnisa, I Dewa Putu Pramantara, Weni Kurdanti

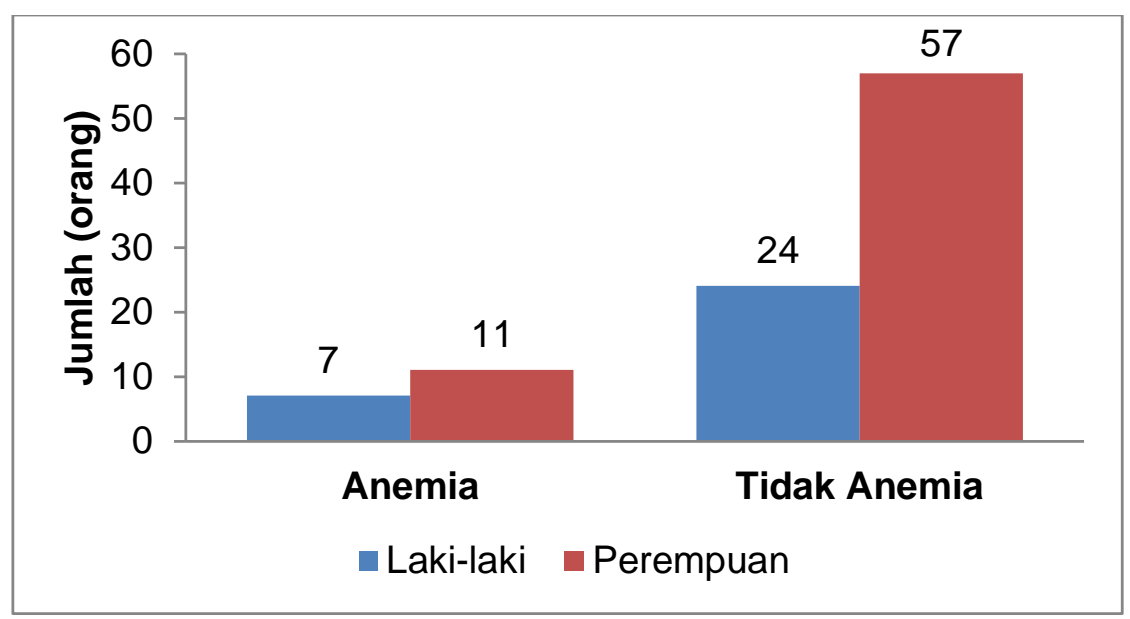

Gambar 1. Status anemia

\section{Status anemia}

Gambar 1 menunjukkan status anemia antara laki-laki dan perempuan yang dikategorikan menjadi anemia dan tidak anemia. Subjek yang mengalami anemia sebanyak 18 orang yaitu pada laki-laki sebanyak 7 orang $(7,1 \%)$ dan pada perempuan sebanyak 11 orang $(11,1 \%)$. Sedangkan subjek yang tidak anemia sebanyak 81 orang yaitu pada laki-laki sebanyak 24 orang $(24,2 \%)$ dan pada perempuan sebanyak 57 orang $(57,6 \%)$. Sehingga dapat disimpulkan bahwa total lansia yang mengalami anemia sebesar $18,2 \%$ dan total lansia yang tidak mengalami anemia sebesar $81,8 \%$.

\section{Hubungan antara asupan protein dengan status anemia}

Uji statistik menunjukkan hasil bahwa terdapat hubungan yang bermakna antara asupan protein dengan status anemia. Hal ini dapat dilihat dari nilai $\mathrm{p}=0,005(\mathrm{p}<0,05)$. Nilai Prevalence Ratio (PR) asupan protein terhadap status anemia sebesar 8,500 (95\% CI 1,182-61,135) (Tabel 3). Sehingga dapat disimpulkan bahwa asupan protein merupakan risiko untuk terjadinya anemia pada lansia yaitu lansia yang asupan proteinnya kurang mempunyai risiko untuk mengalami anemia 8,5 kali lebih besar jika dibandingkan dengan yang asupan proteinnya cukup.

\section{Hubungan antara asupan zat besi dengan status anemia}

Uji statistik menunjukkan hasil bahwa terdapat hubungan yang bermakna antara asupan zat besi dengan status anemia. Hal ini dapat dilihat dari nilai $\mathrm{p}=0,007(\mathrm{p}<0,05)$. Nilai Prevalence Ratio (PR) asupan zat besi terhadap status anemia sebesar 3,017 (95\% CI 1,325-6,870) (Tabel 3). Sehingga dapat disimpulkan bahwa asupan zat besi merupakan risiko untuk terjadinya anemia pada lansia yaitu lansia yang asupan zat besinya kurang mempunyai risiko untuk mengalami anemia 3,017 kali lebih besar jika dibandingkan dengan yang asupan zat besinya cukup.

\section{Hubungan antara asupan vitamin $\mathrm{C}$ dengan status anemia}

Uji statistik menunjukkan hasil bahwa tidak terdapat hubu ngan yang bermakna antara asupan vitamin $\mathrm{C}$ dengan status anemia. Hal ini dapat dilihat dari nilai $\mathrm{p}=0,636(\mathrm{p}>0,05)$. Nilai Prevalence Ratio $(\mathrm{PR})$ asupan vitamin $\mathrm{C}$ terhadap status anemia sebesar 1,225 (95\% CI 0,528-2,843) (Tabel 3). Sehingga dapat disimpulkan bahwa data yang ada belum dapat disimpulkan bahwa faktor yang dikaji benar-benar merupakan faktor risiko atau faktor protektif. 
JKT, 2017;8(2):84-93. Hubungan antara Asupan Protein, Zat Besi, Vitamin C,

Allia Khairunnisa, I Dewa Putu Pramantara, Weni Kurdanti

Tabel 3. Hubungan antara asupan protein, zat besi, dan vitamin $\mathrm{C}$ dengan status anemia

\begin{tabular}{|c|c|c|c|c|c|c|c|}
\hline \multirow{3}{*}{ Asupan Zat Gizi } & \multicolumn{4}{|c|}{ Status Anemia } & \multirow{3}{*}{$\mathrm{p}$} & \multirow{3}{*}{ PR } & \multirow{3}{*}{$95 \% \mathrm{CI}$} \\
\hline & \multicolumn{2}{|c|}{ Anemia } & \multicolumn{2}{|c|}{ Tidak Anemia } & & & \\
\hline & $n$ & $\%$ & $\mathrm{n}$ & $\%$ & & & \\
\hline \multicolumn{8}{|l|}{ Protein } \\
\hline Kurang & 17 & 25,8 & 49 & 74,2 & $0,005^{*}$ & 8,500 & $1,182-61,135$ \\
\hline Cukup & 1 & 3,0 & 32 & 97,0 & & & \\
\hline \multicolumn{8}{|l|}{ Zat Besi } \\
\hline Kurang & 10 & 34,5 & 19 & 65,5 & $0,007 *$ & 3,017 & $1,325-6,870$ \\
\hline Cukup & 8 & 11,4 & 62 & 88,6 & & & \\
\hline \multicolumn{8}{|l|}{ Vitamin C } \\
\hline Kurang & 10 & 20,0 & 40 & 80,0 & 0,636 & 1,225 & $0,528-2,843$ \\
\hline Cukup & 8 & 16,3 & 41 & 83,7 & & & \\
\hline
\end{tabular}

Keterangan : $\quad *$ Signifikan pada $\mathrm{p}<0,05$

$\mathrm{PR}=$ prevalence ratio

$\mathrm{CI}=$ confidence interval (tingkat kepercayaan 95\%)

Hubungan antara asupan inhibitor absorpsi zat besi dengan status anemia

Uji statistik menunjukkan hasil bahwa tidak terdapat hubungan yang bermakna antara asupan tanin dengan status anemia. Hal ini dapat dilihat dari nilai $\mathrm{p}=0,184(\mathrm{p}>0,05)$. Nilai Prevalence Ratio (PR) asupan tanin terhadap status anemia sebesar 0,553 (95\% CI 0,226-1,357) (Tabel 4). Sehingga dapat disimpulkan bahwa data yang ada belum dapat disimpulkan bahwa faktor yang dikaji benar-benar merupakan faktor risiko atau faktor protektif.

Uji statistik menunjukkan hasil bahwa tidak terdapat hubungan yang bermakna antara asupan fitat dengan status anemia. Hal ini dapat dilihat dari nilai $\mathrm{p}=0,129(\mathrm{p}>0,05)$. Nilai Prevalence Ratio (PR) asupan fitat terhadap status anemia sebesar 0,510 (95\% CI 0,208-1,252) (Tabel 4). Sehingga dapat disimpulkan bahwa data yang ada belum dapat disimpulkan bahwa faktor yang dikaji benar-benar merupakan faktor risiko atau faktor protektif.

Uji statistik menunjukkan hasil bahwa tidak terdapat hubungan yang bermakna antara asupan asam oksalat dengan status anemia. Hal ini dapat dilihat dari nilai $\mathrm{p}=0,393(\mathrm{p}>0,05)$. Nilai Prevalence Ratio (PR) asupan asam oksalat terhadap status anemia sebesar 1,440 (95\% CI 0,621-3,342) (Tabel 4). Sehingga dapat disimpulkan bahwa data yang ada belum dapat disimpulkan bahwa faktor yang dikaji benar-benar merupakan faktor risiko atau faktor protektif.

Tabel 4. Hubungan antara asupan inhibitor absorpsi zat besi dengan status anemia

\begin{tabular}{|c|c|c|c|c|c|c|c|}
\hline \multirow{3}{*}{$\begin{array}{l}\text { Asupan Inhibitor } \\
\text { Absorpsi Zat Besi }\end{array}$} & \multicolumn{4}{|c|}{ Status Anemia } & \multirow{3}{*}{$\mathrm{p}$} & \multirow{3}{*}{ PR } & \multirow{3}{*}{$95 \% \mathrm{CI}$} \\
\hline & \multicolumn{2}{|c|}{ Anemia } & \multicolumn{2}{|c|}{ Tidak Anemia } & & & \\
\hline & $\mathrm{n}$ & $\%$ & $n$ & $\%$ & & & \\
\hline \multicolumn{8}{|l|}{ Tanin } \\
\hline Tinggi & 6 & 12,8 & 41 & 87,2 & 0,184 & 0,553 & $0,226-1,357$ \\
\hline Rendah & 12 & 23,1 & 40 & 76,9 & & & \\
\hline \multicolumn{8}{|l|}{ Fitat } \\
\hline Tinggi & 6 & 12,2 & 43 & 87,8 & 0,129 & 0,510 & $0,208-1,252$ \\
\hline Rendah & 12 & 24,0 & 38 & 76,0 & & & \\
\hline \multicolumn{8}{|l|}{ Asam Oksalat } \\
\hline Tinggi & 10 & 21,7 & 36 & 78,3 & 0,393 & 1,440 & $0,621-3,342$ \\
\hline Rendah & 8 & 15,1 & 45 & 84,9 & & & \\
\hline
\end{tabular}

Keterangan : $\mathrm{PR}=$ prevalence ratio

$\mathrm{CI}=$ confidence interval (tingkat kepercayaan 95\%) 
JKT, 2017;8(2):84-93. Hubungan antara Asupan Protein, Zat Besi, Vitamin C,

Allia Khairunnisa, I Dewa Putu Pramantara, Weni Kurdanti

\section{Analisis multivariat (regresi logistik)}

Hasil analisis multivariat menggunakan regresi logistik menunjukkan hasil bahwa hubungan paling bermakna antara asupan protein, asupan zat besi, asupan tanin, dan asupan fitat dengan status anemia ditunjukkan dengan nilai PR. Sehingga, variabel yang berpengaruh terhadap status anemia adalah asupan protein. Kekuatan hubungan dapat dilihat dari nilai PR paling besar yaitu pada asupan protein adalah 6,817 (Tabel 5).

Tabel 5. Analisis multivariat (regresi logistik)

\begin{tabular}{cccc}
\hline Variabel & $\mathrm{p}($ Sig. $)$ & PR $(\operatorname{Exp}(\mathrm{B}))$ & $95 \% \mathrm{CI}$ \\
\hline Protein & 0,081 & 6,817 & $0,787-59,050$ \\
Zat Besi & 0,139 & 2,343 & $0,759-7,233$ \\
Tanin & 0,812 & 0,812 & $0,182-3,797$ \\
Fitat & 0,763 & 0,763 & $0,173-3,623$ \\
\hline
\end{tabular}

\section{BAHASAN}

\section{Hubungan antara asupan protein dengan status anemia}

Berdasarkan hasil penelitian, asupan protein menunjukkan hubungan yang bermakna dengan status anemia pada lansia. Sebagian besar asupan protein subjek tergolong kurang karena lansia membatasi dan menghindari asupan protein hewani. Padahal, protein hewani memiliki kandungan protein yang tinggi. Hal ini karena dipengaruhi beberapa penyebab, diantaranya adalah gigi yang sudah tidak kuat mengunyah makanan yang keras dan berserat seperti daging, tidak menyukai ikan karena berbau amis dan tidak terbiasa mengonsumsi, faktor ekonomi terhadap daya beli untuk membeli bahan makanan protein hewani, serta informasi bahwa sebagian besar protein hewani mengandung kolesterol dan asam urat yang tinggi. Hasil ini sesuai dengan penelitian di Inggris yang menyatakan bahwa ada hubungan yang bermakna antara asupan protein dengan kadar hemoglobin pada usia yang lebih tua ${ }^{(14)}$. Selain itu, hasil penelitian di Indonesia menyatakan bahwa sebagian besar lansia asupan proteinnya kurang karena kurang mengonsumsi bahan makanan sumber protein hewani terutama daging akibat kesulitan mengunyah sehingga lansia lebih memilih makanan sumber protein nabati seperti tahu dan tempe $\mathrm{e}^{(15)}$.

\section{Hubungan antara asupan zat besi dengan status anemia}

Berdasarkan hasil penelitian, asupan zat besi menunjukkan hubungan yang bermakna dengan status anemia pada lansia. Sebagian besar asupan protein subjek tergolong cukup karena lansia mencukupi kebutuhan zat besi dengan mengonsumsi bahan makanan sumber zat besi nonheme seperti tahu dan tempe yang dikonsumsi setiap hari oleh sebagian besar lansia. Tahu dan tempe mempunyai nilai zat besi yang tinggi dan juga merupakan bahan makanan yang murah serta tersedia setiap hari. Hasil ini sesuai dengan penelitian di Inggris yang menyatakan bahwa ada hubungan yang bermakna antara asupan zat besi dengan kadar hemoglobin ${ }^{(14)}$. Selain itu, hasil penelitian di Denmark menyatakan bahwa status besi berhubungan positif dengan asupan zat besi. Asupan zat besi yang cukup dapat mempertahankan status besi pada lansia yang berusia 80 tahun sehingga prevalensi anemia defisiensi besi menjadi rendah ${ }^{(16)}$.

\section{Hubungan antara asupan vitamin $\mathrm{C}$ dengan status anemia}

Berdasarkan hasil penelitian, asupan vitamin $\mathrm{C}$ menunjukkan hubungan yang tidak bermakna dengan status anemia pada lansia. Sebagian besar asupan protein subjek tergolong kurang, tetapi jumlah lansia yang memiliki asupan vitamin $\mathrm{C}$ kurang dan yang memiliki asupan vitamin $\mathrm{C}$ cukup ada keseimbangan. Lansia dengan asupan vitamin $\mathrm{C}$ kurang tidak dapat mengonsumsi sayuran berserat karena ada kesulitan mengunyah dan tidak mampu membeli buah karena harga yang mahal. Lansia dengan asupan vitamin $\mathrm{C}$ cukup, lansia rutin mengonsumsi sayuran dan buah sebagai bahan makanan sumber vitamin $\mathrm{C}$ alami yang baik untuk kesehatan. Hasil ini senada dengan penelitian di Swiss yang menyatakan bahwa tidak ada 
JKT, 2017;8(2):84-93. Hubungan antara Asupan Protein, Zat Besi, Vitamin C, Allia Khairunnisa, I Dewa Putu Pramantara, Weni Kurdanti

hubungan yang bermakna antara absorpsi zat besi dengan asupan zat gizi, salah satunya dari asupan vitamin C. Efek dari absorpsi zat besi oleh vitamin C lebih sedikit jika dibandingkan zat gizi lainnya, seperti fosfat. Fosfat memiliki efek inhibitor absorpsi zat besi yang signifikan jika dibandingkan dengan efek enhancer absorpsi zat besi pada vitamin C maupun protein hewani ${ }^{(6)}$. Selain itu, hasil penelitian di Amerika menyatakan bahwa asam askorbat tidak berpengaruh terhadap absorpsi zat besi dengan hemoglobin, tetapi jika melihat pengaruh asam askorbat dengan serum ferritin memiliki pengaruh yang lebih tinggi karena serum ferritin dapat mendeteksi pengaruh perbedaan pemberian suplementasi asam askorbat serta dapat melihat simpanan zat besi ${ }^{(17)}$.

\section{Hubungan antara asupan inhibitor absorpsi zat besi dengan status anemia}

Berdasarkan hasil penelitian, asupan tanin menunjukkan hubungan yang tidak bermakna dengan status anemia pada lansia. Sebagian besar asupan tanin subjek tergolong rendah, tetapi jumlah lansia yang memiliki asupan tanin tinggi dan yang memiliki asupan tanin rendah ada keseimbangan. Lansia dengan asupan tanin tinggi karena setiap hari mengonsumsi teh. Sedangkan lansia dengan asupan tanin kurang karena tidak menyukai teh dan tidak mengonsumsi teh setiap hari. Teh merupakan sumber tanin dan memiliki kandungan tanin yang tinggi. Hasil ini sesuai dengan penelitian di Belgia yang menyatakan bahwa konsumsi teh (tanin) tidak mempengaruhi status besi karena sebagian besar orang memiliki simpanan besi yang memadai ${ }^{(18)}$. Selain itu, hasil penelitian di Denmark juga menyatakan bahwa konsumsi teh berhubungan negatif dengan status besi karena simpanan besi yang cukup tidak mempengaruhi status besi ${ }^{(16)}$.

Berdasarkan hasil penelitian, asupan fitat menunjukkan hubungan yang tidak bermakna dengan status anemia pada lansia. Sebagian besar asupan fitat subjek tergolong rendah, tetapi jumlah lansia yang memiliki asupan fitat tinggi dan yang memiliki asupan fitat rendah ada keseimbangan. Lansia dengan asupan fitat tinggi karena setiap hari mengonsumsi beras dalam jumlah banyak dan frekuensi sering, yaitu 3 kali sehari. Sedangkan lansia dengan asupan fitat kurang karena setiap hari mengonsumsi beras dalam jumlah sedikit dan frekuensi jarang, yaitu 1-2 kali sehari. Konsumsi tahu dan tempe tidak berpengaruh karena kandungan zat besi pada tahu dan tempe lebih tinggi dibandingkan kandungan fitat sebagai inhibitor absorpsi zat besi. Beras dan kacang-kacangan merupakan sumber fitat dan memiliki kandungan fitat yang tinggi. Hasil ini senada dengan penelitian di Swiss yang menyatakan bahwa tidak ada perbedaan yang signifikan antara inhibitor absorpsi zat besi fitat dengan absorpsi zat besi nonheme karena kurang interaksi antara fitat dan protein kedelai ${ }^{(19)}$. Kedelai dan hasil olahannya memiliki kandungan zat besi yang tinggi sehingga pengaruh akhir terhadap absorpsi zat besi adalah $\operatorname{positif}^{(20)}$.

Berdasarkan hasil penelitian, asupan asam oksalat menunjukkan hubungan yang tidak bermakna dengan status anemia pada lansia. Sebagian besar asupan asam oksalat subjek tergolong rendah, tetapi jumlah lansia yang memiliki asupan asam oksalat tinggi dan yang memiliki asupan asam oksalat rendah ada keseimbangan. Lansia dengan asupan asam oksalat tinggi karena lansia rutin mengonsumsi sayuran sebagai bahan makanan alami yang baik untuk kesehatan serta masih dapat mengonsumsi kacang tanah. Sedangkan lansia dengan asupan asam oksalat kurang karena lansia tidak dapat mengonsumsi sayuran berserat serta tidak dapat mengonsumsi kacang tanah akibat ada kesulitan mengunyah. Sayuran dan kacang-kacangan seperti bayam, brokoli, daun pepaya, kacang tanah merupakan sumber asam oksalat dan memiliki kandungan asam oksalat yang tinggi. Hasil ini sesuai dengan penelitian di India yang menyatakan bahwa tidak ada hubungan yang bermakna antara asam oksalat dengan absorpsi zat besi. Pada beberapa sayuran yang mengandung asam oksalat, justru inhibitor absorpsi zat besi dipengaruhi oleh inhibitor absorpsi zat besi lain seperti fitat dan polifenol sehingga absorpsi zat besi menjadi rendah ${ }^{(7)}$. Selain itu, hasil penelitian di Swiss menyatakan bahwa asam oksalat tidak mempengaruhi absorpsi zat besi karena asam oksalat dalam sayuran dan buah-buahan kurang berinteraksi dengan zat besi. Absorpsi zat besi pada sayuran yang mengandung asam oksalat tidak mencapai tingkat signifikansi karena kandungan polifenol yang lebih tinggi ${ }^{(21)}$ 
JKT, 2017;8(2):84-93. Hubungan antara Asupan Protein, Zat Besi, Vitamin C,

Allia Khairunnisa, I Dewa Putu Pramantara, Weni Kurdanti

\section{SIMPULAN}

Ada hubungan yang bermakna antara asupan protein dan asupan zat besi dengan status anemia pada lanjut usia. Asupan protein dan asupan zat besi merupakan faktor risiko. Asupan protein merupakan variabel paling berpengaruh untuk terjadinya anemia pada lanjut usia. Selain itu, tidak ada hubungan yang bermakna antara asupan vitamin $\mathrm{C}$ dan asupan inhibitor absorpsi zat besi (tanin, fitat, asam oksalat) dengan status anemia pada lanjut usia.

\section{SARAN}

Berdasarkan hasil penelitian diketahui bahwa status anemia terbukti berhubungan dengan asupan protein dan asupan zat besi, sehingga diperlukan sosialisasi kepada lanjut usia maupun keluarga yang tinggal bersama lanjut usia untuk mengonsumsi bahan makanan yang mengandung tinggi protein dan tinggi zat besi untuk mengurangi prevalensi anemia pada lanjut usia. Selain itu, dari hasil penelitian juga diketahui bahwa status anemia terbukti tidak berhubungan dengan asupan vitamin $\mathrm{C}$ dan asupan inhibitor absorpsi zat besi (tanin, fitat, asam oksalat), sehingga penelitian mengenai pengaruh asupan vitamin $\mathrm{C}$, asupan inhibitor absorpsi zat besi (tanin, fitat, asam oksalat), dan faktor risiko lain terhadap status anemia pada lanjut usia perlu dianalisis dengan metode penelitian yang lebih sensitif pada penelitian selanjutnya. Salah satunya dengan pengukuran serum ferritin karena dapat mengetahui status besi dalam hati yaitu lokasi penyimpanan zat besi sehingga faktor risiko yang diteliti memiliki hubungan yang bermakna dengan status anemia.

\section{UCAPAN TERIMA KASIH}

Ucapan terima kasih ditujukan pada seluruh pihak yang tidak disebutkan satu per satu yang banyak memberikan bantuan dan dukungan dalam menyelesaikan penelitian ini.

\section{RUJUKAN}

1. Guralnik, J. M., Ershler, W. B., Schrier, S. L., dan Picozzi, V. J. (2005) Anemia in the Elderly: A Public Health Crisis in Hematology. American Society of Hematology, pp. 528-32.

2. Bross, M. H., Soch, K., dan Knuppel, T. S. (2010) Anemia in Older Persons. American Family Physician, Vol. 82, No. 5, pp. 480-7.

3. Besral, Meilianingsih, L., dan Sahar, J. (2007) Pengaruh Minum Teh terhadap Kejadian Anemia pada Usila di Kota Bandung. Makara Kesehatan, Vol. 11, No. 1, pp. 38-43.

4. Friedman, M. L. dan Wintraub, N. (1997) Proses penuaan yang normal dan pola kelainan hematologi. The Merck Manual of Geriatrics jilid 2. Jakarta: Binarupa Aksara.

5. Hallberg, L. dan Hulthen, L. (2000) Prediction of dietary iron absorption: an algorithm for calculating absorption and bioavailability of dietary iron. Am J Clin Nutr, Vol. 71, pp. 1147-60.

6. Cook, J. D. dan Reddy, M. B. (2001) Effect of ascorbic acid intake on nonheme-iron absorption from a complete diet. Am J Clin Nutr, Vol. 73, pp. 93-8.

7. Gillooly, M., Bothwell, T. H., Torrance, J. D., MacPhail, A. P., Derman, D. P., Bezwoda, W. R., Mills, W., Charlton, R. W., dan Mayet, F. (1983). The effects of organic acids, phytates and polyphenols on the absorption of iron from vegetables. Br J Nutr, Vol. 49, pp. 331-42.

8. Noonan, S. C. dan Savage, G. P. (1999). Oxalate content of foods and its effect on humans. Asia Pacific J Clin Nutr, Vol. 8, pp. 64-74.

9. Chai, W. dan Liebman, M. (2005) Oxalates content of legumes, nuts, and grain-based flours. Journal of Food Compositions and Analysis, Vol. 18, pp. 723-9.

10. Gibney, M. J., Margetts, B. M., Kearney, J. M., dan Arab, L. (2009) Gizi Kesehatan Masyarakat. Jakarta: Penerbit Buku Kedokteran EGC.

11. Supariasa, I. D. N., Bakri, B., dan Fajar I. (2002) Penilaian Status Gizi. Jakarta: Penerbit Buku Kedokteran EGC.

12. Susilo, J. (2000) Hubungan Intake Zat Besi, Tanin, Fitat, Oksalat, dan Kalsium dengan Kadar Hemoglobin Ibu Hamil di Kabupaten Bantul Propinsi DIY. Tesis, Universitas Gadjah Mada. 
JKT, 2017;8(2):84-93. Hubungan antara Asupan Protein, Zat Besi, Vitamin C,

Allia Khairunnisa, I Dewa Putu Pramantara, Weni Kurdanti

13. Marcenes, W., Steele, J. G., Sheiham, A., dan Walls, A. W. G. (2003) The relationship between dental status, food selection, nutrient intake, nutritional status, and body mass index in older people. Cad. Saude Publica, Vol. 19, No. 3, pp. 809-16.

14. Doyle, W., Crawley, H., Robert, H., dan Bates, C. J. (1999) Iron deficiency in older people: Interactions between food and nutrient intakes with biochemical measures of iron; further analysis of the National Diet and Nutrition Survey of people aged 65 years and over. Eur J Clin Nutr, Vol. 53, pp. 552-9.

15. Wijaya, A. M., Pramantara, I. D. P., dan Pangastuti, R. (2012) Status kesehatan oral dan asupan zat gizi berhubungan dengan status gizi lansia. Jurnal Gizi Klinik Indonesia, Vol. 8, No. 3, pp. 151-7.

16. Milman, N., Pedersen, A. N., Ovesen, L., dan Schroll, M. (2004) Iron status in 358 apparently healthy 80 year olde Danish men and women: relation to food composition and dietary and supplemental iron intake. Ann Hematol, Vol. 83, pp. 423-9.

17. Hunt, J. R., Gallagher, S. K., dan Johnson L. K. (1994) Effect of ascorbic acid on apparent iron absorption by women with low iron stores. Am J Clin Nutr, Vol. 59, pp. 1381-5.

18. Temme, E. H. M. dan Van Hoydonck, P. G. A. (2002) Tea consumption and iron status. Eur J Clin Nutr, Vol. 56, pp. 379-86.

19. Reddy, M. B., Hurrell, R. F., Juillerat, M. A., dan Cook, J. D. (1996) The influence of different protein source on phytate inhibition of nonheme-iron absorption in humans. Am J Clin Nutr, Vol. 63, pp. 203-7.

20. Almatsier, S. (2009) Prinsip Dasar Ilmu Gizi. Jakarta: PT Gramedia Pustaka Utama.

21. Bonsmann, S. S. G., Walczyk, T., Renggli, S., dan Hurrell, R. F. (2008) Oxalic acid does not influence nonhaem iron absorption in humans: a comparison of kale and spinach meals. Eur J Clin Nutr, Vol. 62, pp 336-41. 